\title{
Walnut Supplementation in the Diet Reduces Oxidative Damage and Improves Antioxidant Status in Transgenic Mouse Model of Alzheimer's Disease
}

\author{
Mirazkar D. Pandareesh, Ved Chauhan and Abha Chauhan* \\ New York State Institute for Basic Research in Developmental Disabilities, Staten Island, New York, USA
}

Accepted 4 June 2018

\begin{abstract}
Our previous study has shown beneficial effects of walnuts on memory and learning skills in transgenic mouse model of Alzheimer's disease (AD-tg). To understand underlying mechanism, we studied here whether walnuts can reduce oxidative stress in AD. From 4 months of age, experimental AD-tg mice were fed diets containing 6\% (T6) or 9\% walnuts (T9) (equivalent to 1 or $1.5 \mathrm{oz}$, of walnuts per day in humans) for 5, 10, or 15 months. The control groups, i.e., AD-tg (T0) and wild-type (Wt) mice, were fed diets without walnuts. Free radicals, i.e., reactive oxygen species (ROS), lipid peroxidation, protein oxidation, and antioxidant enzymes were assessed in these mice at different ages. AD-tg mice on control diet (T0) showed significant age-dependent increase in ROS levels, lipid peroxidation, and protein oxidation coupled with impaired activities of antioxidant enzymes [superoxide dismutase, catalase, and glutathione peroxidase] compared to Wt mice. Oxidative stress was significantly reduced in AD-tg mice on diets with walnuts (T6, T9), as evidenced by decreased levels of ROS, lipid peroxidation, and protein oxidation, as well as by enhanced activities of antioxidant enzymes compared to T0 mice. Long-term supplementation with walnuts for 10 or 15 months was more effective in reducing oxidative stress in AD-tg mice. Our findings indicate that walnuts can reduce oxidative stress, not only by scavenging free radicals, but also by protecting antioxidant status, thus leading to reduced oxidative damage to lipids and proteins in AD. Therefore, by reducing oxidative stress, a walnut-enriched diet may help reduce the risk or delay the onset and progression of AD.
\end{abstract}

Keywords: Alzheimer's disease, antioxidants, catalase, glutathione, lipid peroxidation, liver, oxidative stress, protein oxidation, reactive oxygen species, superoxide dismutase, walnuts

\section{INTRODUCTION}

Alzheimer's disease (AD) is the most prevalent form of dementia in elderly people. AD is an agedependent neurodegenerative disorder characterized by neuronal loss and the accumulation of neurotoxic amyloid- $\beta(\mathrm{A} \beta)$ as amyloid plaques, and of paired helical filaments as neurofibrillary tangles

${ }^{*}$ Correspondence to: Abha Chauhan, New York State Institute for Basic Research in Developmental Disabilities, Staten Island, New York, USA. Tel.: +1 718494 5258; Fax: +1 718698 7916; E-mail: abha.chauhan@opwdd.ny.gov.
(NFTs) in the brain [1,2]. Oxidative stress is a process induced by an imbalance in the redox state, involving excess free radical generation or the dysfunction of the antioxidant system [3]. Extensive evidence from experimental models and human brain studies suggests a key role of oxidative stress in the development and progression of AD pathology [4-9]. Increased lipid peroxidation, protein oxidation, and DNA oxidation have been reported in the brain, cerebrospinal fluid (CSF), and plasma of AD patients. Enhanced oxidative damage has also been demonstrated in the brains and blood of patients with mild cognitive impairment (MCI) and in CSF from 
subjects with early signs of dementia [10-15]. Several studies have suggested that $A \beta$-induced oxidative stress is involved in the synaptic impairment and neuronal loss in $\mathrm{AD}$ [16-19]. $\mathrm{A} \beta$ has been reported to increase the levels of free radicals, i.e., reactive oxygen species (ROS), hydrogen peroxide, and lipid peroxides, in various cell lines and AD transgenic mice.

Recent studies from our group and others have suggested that walnuts in the diet may improve cognitive function in normal individuals and in $\mathrm{AD}$ [20-22]. We have reported beneficial effects of walnut-enriched diet on memory, learning skills, motor coordination, locomotor activity, and anxiety in the Tg2576 transgenic mouse model of $\mathrm{AD}$ (AD-tg) [23]. In an in vitro study, walnut extract also inhibited the fibrillization of synthetic $A \beta$ and solubilized preformed $A \beta$ fibrils [24]. In two independent PREDIMED (Prevención con Dieta Mediterránea) clinical trials, adult participants on a Mediterranean diet supplemented with mixed nuts ( $15 \mathrm{~g}$ walnuts, $7.5 \mathrm{~g}$ almonds, and $7.5 \mathrm{~g}$ hazelnuts) showed significant improvement in memory relative to baseline, and better cognitive function than the low-fat control group [25, 26]. In another study, long-term higher intake of nuts (particularly walnuts) was associated with better cognitive performance in older women [27]. The National Health and Nutrition Examination Study (NHANES) also showed a positive association between walnuts consumption and cognition scores in adults [28].

The exact mechanism by which diet with walnuts can help to reduce the risk of dementia or slow the onset or progression of the $\mathrm{AD}$ is not known. Walnuts (Juglans regia L.) are rich in components with antioxidant and anti-inflammatory properties. They are an excellent source of $\alpha$-linolenic acid (plant-based omega-3 fatty acid) and antioxidants such as flavonoids, phenolic acid (ellagic acid), melatonin, gamma tocopherol (vitamin E), melatonin, and selenium [29-34]. In terms of antioxidant content, walnuts ranked second when 1,113 different food items were tested [31]. Among nuts, walnuts exhibited the best antioxidant efficiency and the highest phenolic content, followed by almonds and cashew nuts [35]. In our previous in vitro study with PC12 cells, walnut extract showed a protective effect against $A \beta$-induced cell death by reducing ROS generation and oxidative stress, inhibiting membrane damage, and attenuating DNA damage [36].

$A \beta$ is generated in both brain and peripheral tissues. A recent report has suggested that bloodderived $A \beta$ can enter the brain and induce $A \beta$-related pathology and functional deficits of neurons [37]. Substantial evidence supports the importance of the liver in the development of AD. Sutcliffe and colleagues have suggested the liver as the source of $\mathrm{A} \beta$ that deposits as plaques in the brain [38]. They reported that the Psen 2 gene encoding presenilin 2, a component of the $\gamma$-secretase, which is involved in $A \beta$ generation is heritable in the liver but not in the brain. Higher expression of presenilin2 in the liver correlated with higher accumulation of $A \beta$ in the brain and development of AD pathology. In their study, peripheral reduction of $A \beta$ in mice could reduce $A \beta$ accumulation in the brains [38]. Furthermore, non-alcoholic fatty liver disease has been reported to induce AD in wild-type mice and accelerate pathological signs of $\mathrm{AD}$ in AD-tg mice [39]. These reports suggest that significant concentrations of $\mathrm{A} \beta$ originate in the liver, circulate in the blood, and enter the brain. To understand the mechanism of the beneficial effects of dietary walnuts to reduce the risk of dementia and $\mathrm{AD}$, the present study was designed to investigate whether dietary supplementation of walnuts (6\% or $9 \%$, equivalent to recommended daily intake of 1 or $1.5 \mathrm{oz}$, respectively, in humans) can reduce oxidative damage and/or improve antioxidant status, thus reducing oxidative stress in the liver of Tg2576 transgenic mouse model of AD.

\section{MATERIALS AND METHODS}

\section{Animals}

Sixty-six transgenic (tg) female mice (B6: SJL-tg (AßPPSWE) 2576Kha) with Swedish double mutations $\mathrm{K} 670 \mathrm{~N}$ and M671L of $\mathrm{A} \beta$ protein precursor (A $\beta P P)$ (hemizygous model \# 001349- T-F) and twenty wild-type (Wt) mice (model \# 001349-W-F) at the age of 11 weeks were purchased from Taconic Farms, Inc., Germantown, NY. Wt mice were littermate controls that were produced in the same litters as the tg mice but did not carry any manipulated gene of interest. The study was conducted with only female mice because premature mortality and aggressiveness have been reported to be lower in this line of female $\operatorname{tg}$ mice compared to male $\operatorname{tg}$ mice. The mice were housed separately, one in each cage in a temperaturecontrolled room $\left(25 \pm 2^{\circ} \mathrm{C}\right)$ in our Institute's animal colony. During acclimatization period of 5 weeks, all the animals were fed with Taconic \#31 diet. From the age of four months, mice were fed a control diet with or without walnuts and water ad libitum. 


\section{Experimental design}

Animal studies were conducted according to the project approved by the Institutional Animal Care and Use Committee of the New York State Institute for Basic Research in Developmental Disabilities. Sixtysix AD-tg mice were randomly divided into three groups: T0, T6, and T9. From 4 months of age, AD-tg (T6 and T9) mice were fed with diets containing 6\% or $9 \%(\mathrm{w} / \mathrm{w})$ walnuts, i.e., equivalent to 1 or $1.5 \mathrm{oz}$, respectively, recommended daily intake of walnuts in human, whereas the control groups, Tg mice (T0) and Wt, were fed with control diet AIN-93G (TD.94045) for 5, 10, or 15 months. The experimental diets were custom-made in pellet form by adding $6 \%$ or $9 \%$ walnuts to AIN-93G (w/w) (Harlan Sprague Dawley Inc., Madison, WI). The detailed composition and its nutritional facts were described in our previous study [23]. In brief, the diets for the experimental and control mice were comparable in the contents of protein $(17.7 \%)$, carbohydrate $(60 \%)$, and fat $(7.2 \%)$ as well as the total calorie intake (protein: $18.8 \mathrm{Kcal}$ $\%$, carbohydrate: $63.9 \mathrm{Kcal} \%$, and fat: $17.3 \mathrm{Kcal} \%$ ). These animals were sacrificed under anesthesia at different time periods, i.e., before the initiation of diet with walnuts (age: 4 months) and after 5, 10, and 15 months of dietary supplementation with walnuts (at 9,14 , and 19 months of age, respectively). The number of animals in each group (Wt, T0, T6 and T9) of different ages was 5-6. The tissue samples were separated and stored at $-80^{\circ} \mathrm{C}$ until further analysis. The oxidative stress markers were examined in the liver tissues of $\mathrm{Wt}$ and $\mathrm{AD}$-tg mice before initiation of walnut diet (age: 4 months) and after supplementation with $6 \%$ or $9 \%$ walnut diet for 5 months (age: 9 months), 10 months (age: 14 months), and 15 months (age: 19 months).

\section{Free radicals, i.e., ROS assay}

ROS levels were measured in the liver tissues of Wt, T0, T6, and T9 mice (ages: 4, 9, 14, or 19 months) by using the fluorescent dye 2',7'dichloro-dihydrofluorescein diacetate (DCFH-DA) [40]. DCFH-DA is a non-ionic dye that crosses the cell membrane, where it is deacetylated to fluorescent DCFH by the intracellular esterases. In the presence of ROS, DCFH converts to the highly fluorescent 2',7'-dichlorofluorescein (DCF). The DCF fluorescence intensity is proportional to the amount of ROS. Briefly, $50 \mathrm{mg}$ of liver tissues were homogenized in $1 \mathrm{ml}$ of phosphate buffer saline (PBS),
$\mathrm{pH}$ 7.0. The liver homogenates were centrifuged at $10,000 \times g$ for $15 \mathrm{~min}$ at $4^{\circ} \mathrm{C}$. To $10 \mu \mathrm{l}$ of supernatants (containing $10 \mu \mathrm{g}$ of protein), $190 \mu \mathrm{l}$ of $1.25 \mathrm{mM}$ DCFH-DA in methanol was added to the wells (96-well dark plate). All samples were incubated at $37^{\circ} \mathrm{C}$ in dark for $15 \mathrm{~min}$. The fluorescence of the samples was measured at an excitation wavelength of $488 \mathrm{~nm}$ and an emission wavelength of $525 \mathrm{~nm}$, using the Spectra-max M5 multi-mode microplate reader (Molecular Devices, CA). The ROS levels are expressed as arbitrary fluorescence unit/mg protein.

\section{Lipid peroxidation assay}

Lipid peroxidation was assessed by measuring the levels of malondialdehyde (MDA), an endproduct and marker of lipid peroxidation. One hundred $\mathrm{mg}$ of liver tissues of Wt and AD-tg mice were homogenized in $2 \mathrm{ml}$ of phosphate buffer ( $\mathrm{pH}$ 7.0). To $0.5 \mathrm{ml}$ of liver homogenates (containing $\sim 5 \mathrm{mg}$ of protein), $0.5 \mathrm{ml}$ of trichloroacetic acid $(10 \%)$ and $2 \mathrm{ml}$ of thiobarbituric acid (TBA) mixture were added. The TBA mixture contained $0.35 \%$ TBA, $0.2 \%$ sodium dodecyl sulfate, $0.05 \mathrm{mM} \mathrm{FeCl}_{3}$, and butylated hydroxytoluene in glycine- $\mathrm{HCl}$ buffer (100 mM, pH 3.6). All samples were kept in boiling water bath for $30 \mathrm{~min}$ and then allowed to cool. The samples were centrifuged at $8,000 \times g$ for $10 \mathrm{~min}$, and the absorbance of the supernatants was measured at $532 \mathrm{~nm}$. The MDA content was calculated by using the molar extinction co-efficient of $1.56 \times 10^{5}$ $\mathrm{M}^{-1} \mathrm{~cm}^{-1}$. MDA levels are expressed as $\mathrm{nmol} / \mathrm{mg}$ protein [41].

\section{Protein oxidation assay}

Protein oxidation was measured as protein carbonyl content, a marker of protein oxidation. The protein carbonyl content in the liver tissues of $\mathrm{Wt}$, T0, T6, and T9 mice (different ages) was estimated by using a protein carbonyl assay kit as per manufacturer's instructions (BioVision, Milpitas, CA). The protein carbonyl content was calculated by using a molar extinction co-efficient of $22 \mathrm{mM}^{-1} \mathrm{~cm}^{-1}$, and the values are expressed as nmol/mg protein.

\section{Estimation of antioxidant enzyme activities}

\section{Superoxide dismutase (SOD)}

The activity of SOD was assayed by using its inhibitory action on quercetin oxidation [42]. 
Briefly, the reaction mixture contained $30 \mathrm{mM}$ Tris-HCl buffer ( $\mathrm{pH}$ 9.1), $0.5 \mathrm{~m}$ EDTA, $50 \mathrm{mM}$ $\mathrm{N}, \mathrm{N}, \mathrm{N}$ ',N'-tetramethylethylenediamine (TEMED), $0.05 \mathrm{mM}$ quercetin, and $10 \mu \mathrm{l}$ soluble liver extract (containing $10 \mu \mathrm{g}$ of protein). The reaction was monitored at an absorbance of $406 \mathrm{~nm}$ for $10 \mathrm{~min}$. One unit of SOD activity was defined as the amount of SOD enzyme (per mg of protein) that inhibits quercetin oxidation reaction by $50 \%$ of maximal value.

\section{Catalase (CAT)}

Catalase activity was assayed using the method of Aebi [43]. Briefly, $1 \mathrm{ml}$ of the reaction mixture containing $50 \mu \mathrm{l}$ of soluble liver extract (containing $\sim 5 \mu \mathrm{g}$ of protein) was mixed with $900 \mu \mathrm{l}$ of phosphate buffer $(0.1 \mathrm{M}, \mathrm{pH} 7.0)$ and $50 \mu$ l of $\mathrm{H}_{2} \mathrm{O}_{2}$ $(8.8 \mathrm{mM})$. The decrease in absorbance at $240 \mathrm{~nm}$ was measured for $3 \mathrm{~min}$ at room temperature. The catalase enzyme activity was determined by using a molar extinction coefficient of $43.6 \mathrm{M}^{-1} \mathrm{~cm}^{-1}$. Catalase activity is expressed as nmol $\mathrm{H}_{2} \mathrm{O}_{2}$ degraded $/ \mathrm{min} / \mathrm{mg}$ protein.

\section{Glutathione peroxidase activity}

Glutathione peroxidase (GPx) activity was determined by using the substrate t-butyl hydroperoxide (tbHP) as described by Flohé and Günzler [44]. Briefly, $10 \mu \mathrm{l}$ soluble liver extract was added to $180 \mu \mathrm{l}$ reaction mixture [containing phosphate buffer (0.1 M; pH 7.4), EDTA (0.5 mM), glutathione reductase $(0.24 \mathrm{U})$, glutathione $(1 \mathrm{mM})$, and NADPH $(0.15 \mathrm{mM})]$ and incubated at $37^{\circ} \mathrm{C}$ for $1 \mathrm{~min}$. The reaction was initiated by the addition of $10 \mu \mathrm{l}$ tbHP $(0.12 \mathrm{mM})$. The change in absorbance was monitored at $340 \mathrm{~nm}$ for $5 \mathrm{~min}$. An extinction coefficient of $6.22 \times 10^{3} \mathrm{M}^{-1} \mathrm{~cm}^{-1}$ was used to determine GPx activity, which is expressed as nmol NADPH oxi$\mathrm{dized} / \mathrm{min} / \mathrm{mg}$ protein.

\section{Protein estimation}

Protein content in the supernatants of liver homogenates of the mice was measured by Bradford's method, by using bovine serum albumin as a standard [45].

\section{Statistical analysis}

The data are expressed as mean \pm standard error of mean (SEM). The statistical comparison was done within T0 group of mice at different ages $(4,9,14$, and 19 months) and between different groups of mice

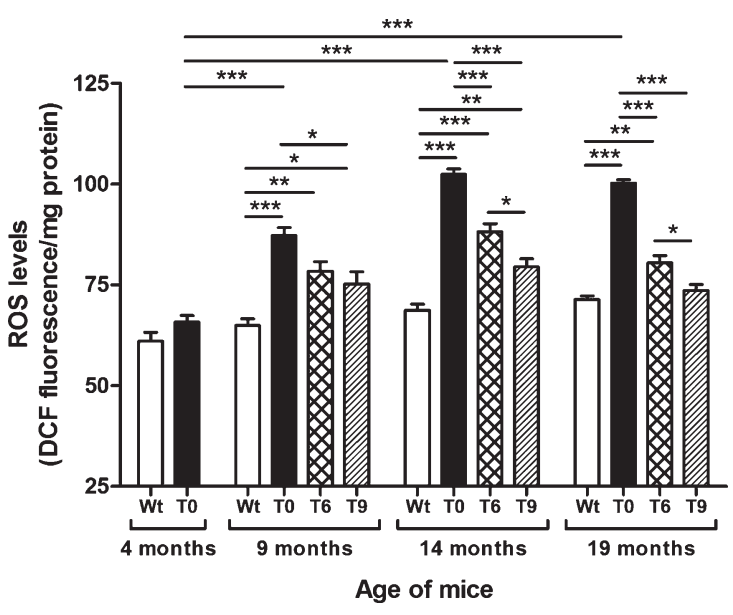

Fig. 1. Effect of dietary walnut supplementation on ROS levels in $\mathrm{AD}$-tg mice. Diet with walnuts was fed to AD-tg mice from the age of 4 months for a period of 5, 10, or 15 months, i.e., until the age of 9,14 , or 19 months. ROS levels in the liver homogenates were measured as DCF fluorescence in arbitrary unit/mg protein. Data are represented as the mean \pm SEM. Wild-type mice on control diet (Wt), AD-tg on control diet (T0), and AD-tg mice on diet containing $6 \%$ walnuts (T6) and $9 \%$ walnuts (T9). ${ }^{*} p<0.05$, ${ }^{* *} p<0.01$, and ${ }^{* * *} p<0.001$.

of the same age. Data were analyzed by one-way ANOVA followed by Tukey's post hoc test using GraphPad Prism 5.0 software. Differences at $p<0.05$ were considered significant.

\section{RESULTS}

Effect of diet with walnuts on ROS levels in AD-tg mice

As shown in Fig. 1, AD-tg mice on the control diet (T0) showed a progressive increase in ROS levels with age in comparison with the 4-month-old T0 group $(p<0.001)$ and with $\mathrm{Wt}$ mice in same age group $(p<0.001)$. The AD-tg mice on diets supplemented with $6 \%$ or $9 \%$ walnuts (T6 and T9) for 10 and 15 months (i.e., until the ages of 14 and 19 months) showed a significant decrease in ROS levels compared to T0 mice $(p<0.001)$. However, after 5 months of walnut supplementation (until the age of 9 months), only the T9 group showed significantly lower ROS levels than T0 $(p<0.05)$. At the ages of 14 and 19 months, diet with $9 \%$ walnuts showed significantly lower ROS levels compared to $6 \%$-walnut $\operatorname{diet}(p<0.05)$. 


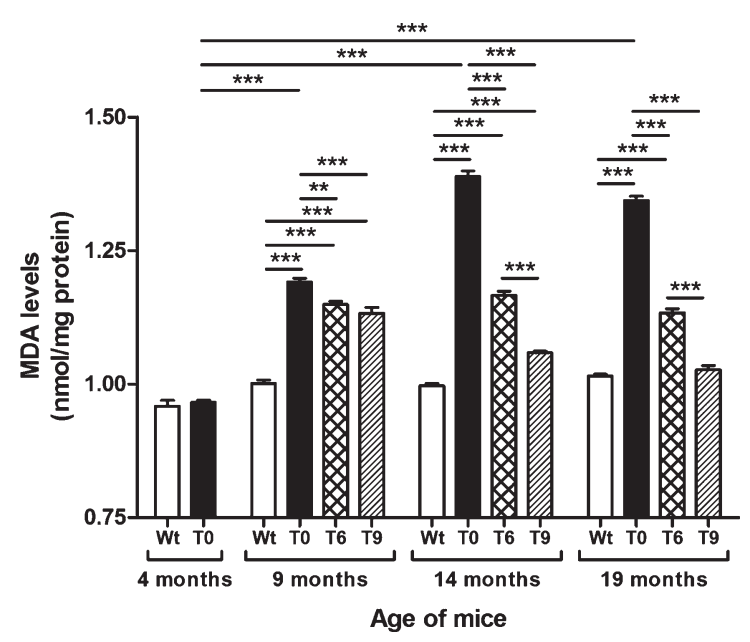

Fig. 2. Effect of dietary walnut supplementation on lipid peroxidation in AD-tg mice. Lipid peroxidation was measured by estimating the levels of MDA, an end-product of lipid peroxidation in the liver homogenates. Diet with walnuts was fed to $\mathrm{AD}$-tg mice from the age of 4 months for a period of 5,10 , or 15 months, i.e., until the age of 9,14 , or 19 months. Data are represented as the mean \pm SEM. Wild-type mice on control diet (Wt), AD-tg on control diet (T0), and AD-tg mice on diet containing 6\% walnuts (T6) and $9 \%$ walnuts (T9). ${ }^{*} p<0.05,{ }^{* *} p<0.01$, and ${ }^{* * *} p<0.001$.

\section{Effect of walnut supplementation in the diet on lipid peroxidation in $A D$-tg mice}

Figure 2 presents the data on lipid peroxidation assessed by estimating the levels of MDA in $\mathrm{Wt}, \mathrm{T} 0$, $\mathrm{T} 6$, and T9 mice. AD-tg mice on the control diet (T0) (age: 9, 14, and 19 months) showed an age-dependent increase in lipid peroxidation as compared with 4month-old T0 mice $(p<0.001)$ and $\mathrm{Wt}$ mice of the same age $(p<0.001)$. AD-tg mice on the $6 \%$ or $9 \%$ walnut diet (T6 and T9) showed a significant decrease in lipid peroxidation compared to $\mathrm{T} 0$ mice at all ages (9 months, $p<0.01$ with T6, $p<0.001$ with T9; 14 months, $p<0.001$; and 19 months, $p<0.001$ ). With long-term supplementation of walnuts for 10 and 15 months, the effect of $9 \%$ walnuts was greater than that of $6 \%$ walnuts $(p<0.001)$, but their effects were similar after short-term walnut supplementation for 5 months.

\section{Effect of walnut supplementation in the diet on protein oxidation in $A D$-tg mice}

Protein oxidation was measured as protein carbonyl content in $\mathrm{Wt}, \mathrm{T} 0, \mathrm{~T} 6$, and $\mathrm{T} 9$ mice, and the data are presented in Fig. 3. AD-tg mice on the control diet (T0) showed an age-dependent increase in protein

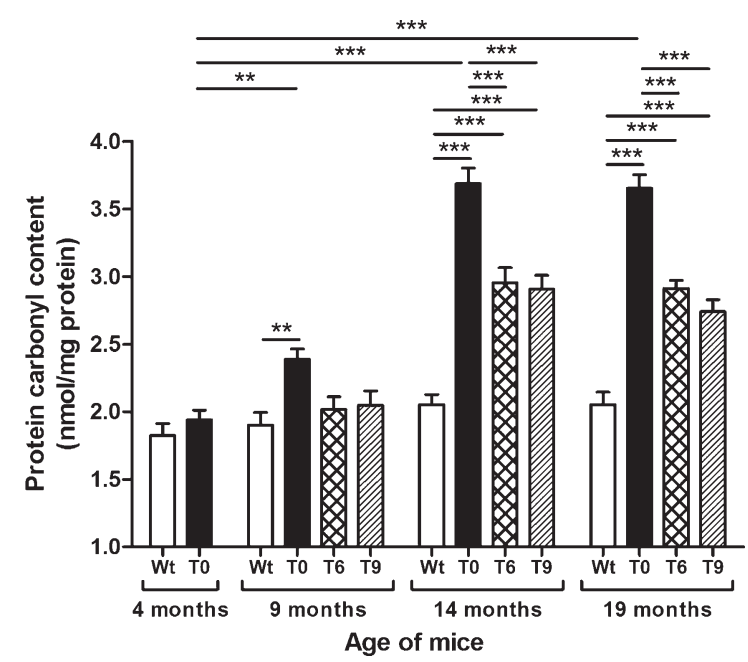

Fig. 3. Effect of dietary walnut supplementation on protein oxidation in AD-tg mice. Protein oxidation was assessed as protein carbonyl content in the liver tissues. Diet with walnuts was fed to AD-tg mice from the age of 4 months for a period of 5,10 , or 15 months, i.e., until the age of 9,14 , or 19 months. Data are represented as the mean \pm SEM. Wild-type mice on control diet (Wt), AD-tg on control diet (T0), and AD-tg mice on diet containing $6 \%$ walnuts (T6) and $9 \%$ walnuts (T9). ${ }^{*} p<0.05,{ }^{* *} p<0.01$, and *** $p<0.001$.

carbonyl content at $9(p<0.01), 14(p<0.001)$, and 19 months $(p<0.001)$ of age in comparison with 4 month-old T0 mice and their respective Wt mice of same age group. AD-tg mice on diet with $6 \%$ or $9 \%$ walnuts (T6 and T9) for 10 or 15 months (14 and 19 months of age) showed a significant decrease in oxidation of proteins compared to T0 mice $(p<0.001)$. Although protein oxidation also decreased in T6 and T9 mice compared to $\mathrm{T} 0$ after 5 months of walnut supplementation (age: 9 months), it was not a significant difference.

\section{Effect of walnut supplementation on superoxide dismutase activity}

As shown in Fig. 4A, SOD activity decreased with increasing age in AD-tg mice on a control diet (T0) in comparison with the 4-month-old T0 group ( $p<0.01$, age: 14 months; $p<0.001$, age: 19 months) and with the respective Wt mice of the same age group $(p<0.001)$. The AD-tg mice supplemented with the diets containing $6 \%$ or $9 \%$ walnuts (T6 and T9) long-term, i.e., 10 and 15 months (until age of 14 and 19 months) showed a significant increase in SOD activity compared to T0 mice $(p<0.001)$. SOD activity was similar between these groups at 9 
A

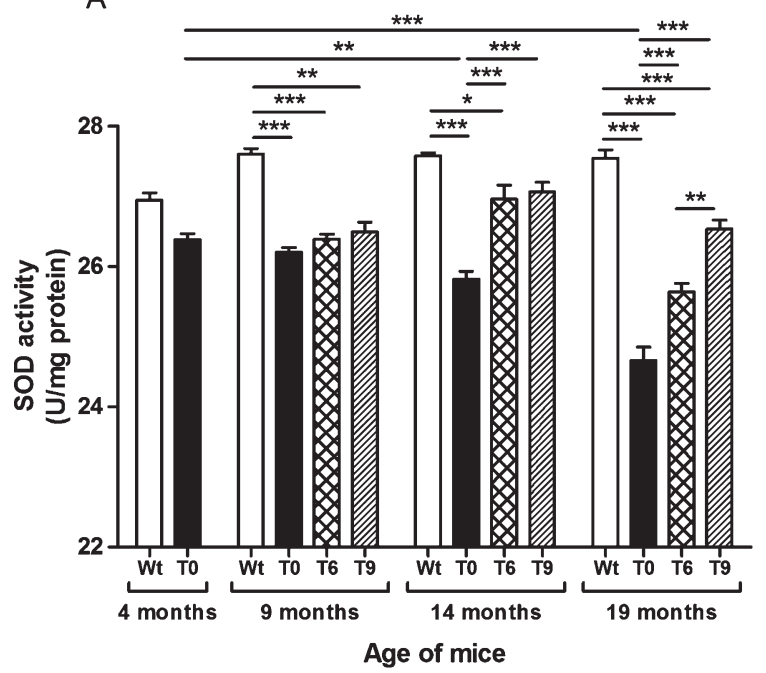

B

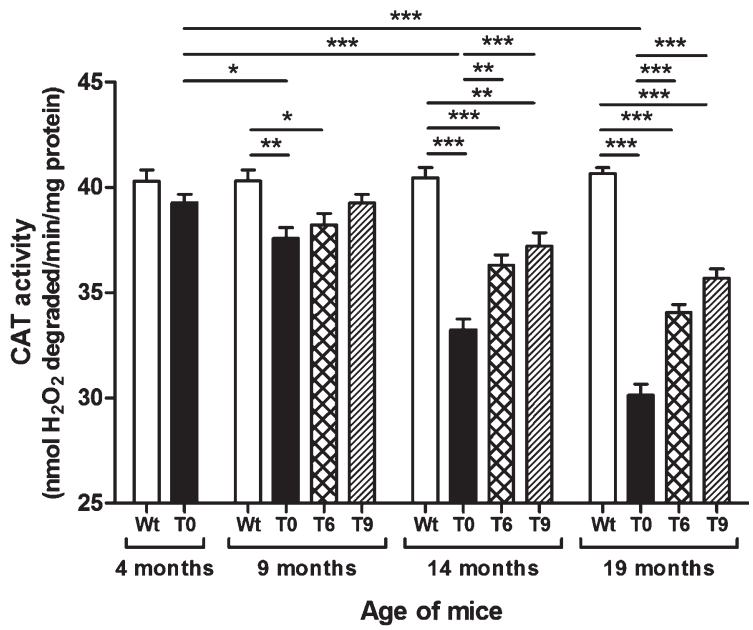

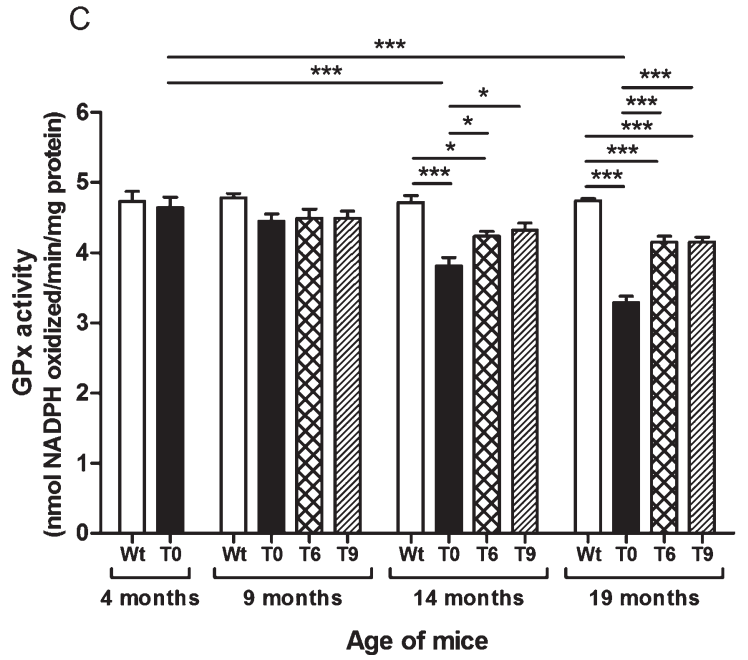

Fig. 4. Effect of walnut supplementation on antioxidant enzymes' activities in AD-tg mice. (A) Superoxide dismutase (SOD), (B) catalase (CAT), and (C) glutathione peroxidase (GPx). Diet with walnuts was fed to AD-tg mice from the age of 4 months for a period of 5, 10, or 15 months, i.e., until the age of 9,14 , or 19 months. Data are represented as the mean \pm SEM. Wild-type mice on control diet (Wt), AD-tg on control diet (T0), and AD-tg mice on diet containing 6\% walnuts (T6) and 9\% walnuts (T9). ${ }^{*} p<0.05,{ }^{* *} p<0.01$, and ${ }^{* * *} p<0.001$.

months of age after 5 months' dietary supplementation with walnuts. In 19-month-old AD-tg mice, the effect of T9 diet was greater than that of T6 diet $(p<0.01)$.

\section{Effect of walnut supplementation on catalase activity}

Our results elucidated that AD-tg mice on the control diet (T0) showed progressive decrease in activity of catalase with age in comparison with the 4-monthold T0 group and with their respective Wt group mice of the same age ( 9 months, $p<0.01 ; 14$ months, $p<0.001$; and 19 months, $p<0.001$ ) (Fig. 4B). The AD-tg mice supplemented with the diets containing $6 \%$ or $9 \%$ walnuts (T6 and T9) showed a significant increase in catalase activity compared to the AD-tg mice on the control diet (T0) at the age of 14 months (T6, $p<0.01 ; \mathrm{T} 9, p<0.001)$ and 19 months (T6 and $\mathrm{T} 9, p<0.001)$. There was no significant difference between the T0, T6, and T9 groups after 5 months of supplementation with walnuts in the diet (age: 9 months). Also, catalase activity with $6 \%$ and $9 \%$ walnut-enriched diets was similar. 


\section{Effect of walnut supplementation on glutathione peroxidase activity}

As shown in Fig. 4C, AD-tg mice on the control diet (T0) showed progressive decrease in GPx activity with age (14 months, $p<0.001$; and 19 months, $p<0.001)$ in comparison with the 4-month-old T0 group and with their respective $\mathrm{Wt}$ group mice of the same age. The AD-tg mice supplemented with the diets containing $6 \%$ or $9 \%$ walnuts (T6 and T9) showed a significant increase in GPx activity compared to the AD-tg mice on the control diet (T0) at the age of 14 months $(p<0.05)$ and 19 months $(p<0.001)$ (Fig. 4C). There was no significant difference between the T0, T6, and T9 groups after 5 months of supplementation with walnuts in the diet (until the age of 14 months). Also, GPx activity with $6 \%$ and $9 \%$ walnut-enriched diets was similar.

\section{DISCUSSION}

The neuropathological changes associated with $\mathrm{AD}$ evolve gradually over decades before the clinical symptoms become evident in affected subjects [10-15]. Several in vitro studies have shown that $\mathrm{A} \beta$ exhibits cytotoxic properties by producing ROS and inducing oxidative stress, which causes oxidative damage of lipids, proteins, and nucleic acids as an important event in AD pathology [16-19]. Our results showed a progressive increase in oxidative stress markers with increasing age in the $\mathrm{Tg} 2576$ transgenic mouse model of AD. These findings support the free radical theory of aging, which postulates increased accumulation of free radicals with age. $A \beta$ synthesis and secretion increase under conditions of oxidative stress and contribute to AD pathology [46]. Evidence also exists that ROS generation increases with $A \beta$ and NFT pathology in AD, thereby creating a vicious cycle of ROS generation that far exceeds the antioxidant defense system [47].

It is interesting that age-dependent increase in oxidative stress markers from 4 to 19 months of age in the liver of $\mathrm{Tg} 2576$ transgenic mouse model of AD observed in present study matched quite well with age of increase in amyloid accumulation in the brain of these AD-tg mice that was previously reported by Kawarabayashi et al. [48]. These authors observed appearance and subsequent increase of insoluble $A \beta$ in the brain beginning at 6-7 months of age in these AD-tg mice. However, at 10 months of age, minimal histological evidence of $A \beta$ deposition in the brain (only isolated $\mathrm{A} \beta$ plaque cores in few sections) was observed. From 10 to 21 months, there was a rapid increase in both diffuse plaques and neuritic plaques with amyloid cores in the brains of these mice, rising to the levels like those observed in the brain of $\mathrm{AD}$ patients. Together, our results of the present study and above report [48] support a relationship between agedependent increase in oxidative stress and amyloid accumulation in AD-tg mice.

The recommended daily serving of walnuts is $1-1.5 \mathrm{oz}$, which equals $6-10$ walnuts. Dietary supplementation with walnuts both at $6 \%$ and $9 \%$ concentration (equivalent to 1 and $1.5 \mathrm{oz} /$ day in humans) in AD-tg mice significantly decreased the levels of free radicals. This may be because polyphenols, flavonoids, vitamin $\mathrm{E}$, and other antioxidant components present in walnuts can serve as natural antioxidants [29-34]. The polyphenols in walnut husks include chlorogenic acid, ferulic acid, gallic acid, ellagic acid, caffeic acid, protocatechuic acid, sinapic acid, syringic acid, vanillic acid, catechin, epicatechin, myricetin, and juglone, and walnut leaves have 3- and 5-caffeoylquinic acids, 3- and 4$p$-coumaroylquinic acids, $p$-coumaric acid, quercetin 3 -galactoside, quercetin 3-arabinoside, quercetin 3-xyloside, quercetin 3-pentoside derivative, and quercetin 3-rhamnoside [49-51].

ROS are highly unstable and easily react with proteins, lipids, and nucleic acids. Lipids are an ideal target for free radical attack and have a crucial role in initiation and propagation of the cascade of reactions that yield many secondary products of lipid oxidation such as hydroperoxides, endoperoxides, and oxysterols. These molecules undergo fragmentation to produce a broad range of reactive carbonyl intermediates such as $\alpha$, $\beta$-unsaturated aldehydes (4-HNE, acrolein), di-aldehydes (MDA, glyoxal), and ketoaldehydes (4-oxo-trans-2-nonenal, isoketals), which are responsible for extensive cellular damage. In the present study, lipid peroxidation progressively increased with age in AD-tg mice. These findings corroborate previous reports showing increased lipid peroxidation in the brains of patients with $\mathrm{AD}$ compared to age-matched controls $[5,7,8]$. In our study, AD-tg mice on diet containing $6 \%$ or $9 \%$ walnuts showed a significant decrease in lipid peroxidation compared to AD-tg mice on the control diet. Walnut supplementation has also been reported to decrease lipid peroxidation and improve learning and memory in hypercholesterolemia mice [52].

ROS by itself or the molecules generated as end products of lipid peroxidation (HNE and MDA) can modify proteins to generate carbonyl derivatives. 
Carbonyl groups are introduced into proteins by oxidizing amino acid (arginine, lysine, proline, and threonine) or glutamyl residues, or from the peptide bonds cleavage via $\alpha$-amidation pathway [53]. The oxidative conversion of protein side-chains to reactive carbonyl or acylating moieties can result in abnormal protein cross-linking [9]. Pathologic aggregation of proteins into fibrils is a characteristic feature of AD. Oxidative modifications cause crosslinking of covalent bonds of proteins, leading to insoluble fibril formation. In AD pathology, the formation of NFTs by protein aggregation and hyperphosphorylation of tau proteins into paired helical filaments is also linked with protein oxidation. Therefore, measurement of protein carbonyl content is considered a good biomarker for the extent of oxidative damage of proteins. In this study, protein oxidation measured as protein carbonyl content increased with age in AD-tg mice. Our findings support previous reports showing an increased rate of protein oxidation with age in rat liver [54] and in the brains of patients with AD compared to age-matched controls $[5,7,55-57]$. In the present study, dietary supplementation with walnuts (6\% or $9 \%$ ) in AD-tg mice resulted in a significant decrease in oxidation of proteins compared to the control diet. Our results in AD-tg mice also indicated that long-term supplementation with walnuts in the diet for 10 or 15 months had more beneficial effects in reducing ROS levels and oxidative damage to lipids and proteins than short-term walnut supplementation for 5 months.

Accumulation of ROS is controlled in vivo by a wide spectrum of non-enzymatic antioxidant systems (such as glutathione) and enzymatic antioxidant systems including SOD, catalase, and GPx. Many studies have shown alterations in the activities of antioxidant enzymes during oxidative stress, aging, and $\mathrm{AD}[5,7,8]$. In this study, we also observed a decrease in the activities of SOD, catalase, and GPx antioxidant enzymes in AD-tg mice. The ADtg mice supplemented with the diets containing $6 \%$ or $9 \%$ walnuts for 10 or 15 months showed a significant increase in these antioxidant enzymatic activities compared to the AD-tg mice on the control diet. However, there was no significant effect of short-term (5 months) walnut supplementation on the activities of these enzymes, suggesting that long-term supplementation of walnuts in the diet is more beneficial in improving antioxidant status in AD. Shi and colleagues also reported that walnut supplementation increased SOD activity in the brain of hypercholesterolemia mice [52]. A recent study showed that walnut supplementation significantly improved SOD, catalase, and GPx activity in scopolamine-induced, memory-impaired rats [58]. Together, our findings suggest that supplementation with walnuts in the diet improved endogenous antioxidant function associated with removing accumulated ROS and improving the balance between ROS and antioxidants, thus reducing oxidative damage to lipids and proteins in AD-tg mice.

Oxidative stress and inflammation are known to be prominent features not only in the aging process and AD but also in other neurological disorders, such as Parkinson's disease (PD), depression, schizophrenia, bipolar disorder, and autism. A recent study in a mouse model of PD showed that walnut extract protected neurons, inhibited oxidative stress, and improved PD symptoms, i.e., motor coordination, postural balance, and movement [59]. SánchezVilegas and colleagues analyzed data on depression among PREDIMED participants, who were on a Mediterranean diet supplemented with nuts and reported a lower rate of depression in these subjects [60]. Furthermore, the risk of depression was $40 \%$ lower among diabetic people who had a nut-enriched Mediterranean diet. The incidence of stroke was also reduced by about $50 \%$ in subjects who were on a Mediterranean diet enriched with mixed nuts [61]. In experimentally induced epilepsy in male rats, the dietary supplementation with walnuts showed anticonvulsant and neuroprotective effects and reduced mortality [62]. Furthermore, other studies have suggested that walnuts in the diet can reduce the risk of cardiovascular diseases [61, 63-65], type 2 diabetes [66, 67], and cancers, including breast [68-70], prostate [71, 72] and colon [73-75] cancers. Together, these reports suggest potential benefits of dietary supplementation with walnuts, not only in neurological disorders, but also in other chronic diseases.

In conclusion, remarkable age-related increases in ROS levels, lipid peroxidation, and protein oxidation were found in the liver of AD-tg mice. In addition, we observed impaired activities of SOD, catalase, and GPX antioxidant enzymes in these mice. Long-term dietary supplementation with $6 \%$ or $9 \%$ walnuts significantly improved antioxidant status and decreased ROS levels, lipid peroxidation, and protein oxidation compared to the control diet. Therefore, dietary supplementation with walnuts may have a beneficial effect on oxidative stress, not only by scavenging free radicals generated, but also by protecting antioxidant status, thus leading to reduced oxidative damage to lipids and proteins. Because cognitive decline and 
dementia develop over many years, early intervention with walnut-enriched diet may help maintain cognitive function and may reduce the risk, or delay the onset and progression, of dementia by reducing oxidative damage and boosting antioxidant defense system. In addition, a diet with walnuts may provide beneficial effects in other brain disorders because of the cumulative effects of the components of walnuts to reduce oxidative stress and inflammation.

\section{ACKNOWLEDGMENTS}

This work was supported in part by funds from the New York State Office for People with Developmental Disabilities, and the California Walnut Commission (to AC).

Authors' disclosures available online (https:// www.j-alz.com/manuscript-disclosures/18-0361r1).

\section{REFERENCES}

[1] Huang HC, Jiang ZF (2009) Accumulated amyloid-beta peptide and hyperphosphorylated tau protein: Relationship and links in Alzheimer's disease. J Alzheimers Dis 16, 15-27.

[2] O'Brien RJ, Wong PC (2011) Amyloid precursor protein processing and Alzheimer's disease. Annu Rev Neurosci 34, 185-204.

[3] Birben E, Sahiner UM, Sackesen C, Erzurum S, Kalayci O (2012) Oxidative stress and antioxidant defense. World Allergy Organ J 5, 9-19.

[4] Bonda DJ, Wang X, Perry G, Nunomura A, Tabaton M, Zhu X, Smith MA (2010) Oxidative stress in Alzheimer disease: A possibility for prevention. Neuropharmacology 59, 290-294.

[5] Chauhan V, Chauhan A (2006) Oxidative stress in Alzheimer's disease. Pathophysiology 13, 195-208.

[6] Galasko D, Montine TJ (2010) Biomarkers of oxidative damage and inflammation in Alzheimer's disease. Biomark Med 4, 27-36.

[7] Wang X, Wang W, Li L, Perry G, Lee HG, Zhu X (2014) Oxidative stress and mitochondrial dysfunction in Alzheimer's disease. Biochim Biophys Acta 1842, 12401247.

[8] Chen Z, Zhong C (2014) Oxidative stress in Alzheimer's disease. Neurosci Bull 30, 271-281.

[9] Perry G, Cash AD, Smith MA (2002) Alzheimer disease and oxidative stress. J Biomed Biotechnol 2, 120-123.

[10] Keller JN, Schmitt FA, Scheff SW, Ding Q, Chen Q, Butterfield DA, Markesbery WR (2005) Evidence of increased oxidative damage in subjects with mild cognitive impairment. Neurology 64, 1152-1156.

[11] Knopman DS, Parisi JE, Salviati A, Floriach-Robert M, Boeve BF, Ivnik RJ, Smith GE, Dickson DW, Johnson KA, Petersen LE, McDonald WC, Braak H, Petersen RC (2003) Neuropathology of cognitively normal elderly. $J$ Neuropathol Exp Neurol 62, 1087-1095.

[12] Schrag M, Mueller C, Zabel M, Crofton A, Kirsch WM, Ghribi O, Squitti R, Perry G (2013) Oxidative stress in blood in Alzheimer's disease and mild cognitive impairment: A meta-analysis. Neurobiol Dis 59, 100-110.

[13] Butterfield DA, Poon HF, St Clair D, Keller JN, Pierce WM, Klein JB, Markesbery WR (2006) Redox proteomics identification of oxidatively modified hippocampal proteins in mild cognitive impairment: Insights into the development of Alzheimer's disease. Neurobiol Dis 22, 223-232.

[14] Pratico D, Clark CM, Liun F, Rokach J, Lee VY, Trojanowski JQ (2002) Increase of brain oxidative stress in mild cognitive impairment: A possible predictor of Alzheimer disease. Arch Neurol 59, 972-976.

[15] Torres LL, Quaglio NB, de Souza GT, Garcia RT, Dati LM, Moreira WL, Loureiro AP, de Souza-Talarico JN, Smid J, Porto CS, Bottino CM, Nitrini R, Barros SB, Camarini R, Marcourakis T (2011) Peripheral oxidative stress biomarkers in mild cognitive impairment and Alzheimer's disease. J Alzheimers Dis 26, 59-68.

[16] Davis JB (1996) Oxidative mechanisms in beta-amyloid cytotoxicity. Neurodegeneration 5, 441-444.

[17] Harris ME, Hensley K, Butterfield DA, Leedle RA, Carney JM (1995) Direct evidence of oxidative injury produced by the Alzheimer's beta-amyloid peptide (1-40) in cultured hippocampal neurons. Exp Neurol 131, 193-202.

[18] Kadowaki H, Nishitoh H, Urano F, Sadamitsu C, Matsuzawa A, Takeda K, Masutani H, Yodoi J, Urano Y, Nagano T, Ichijo H (2005) Amyloid beta induces neuronal cell death through ROS-mediated ASK1 activation. Cell Death Differ 12, 19-24.

[19] Sponne I, Fifre A, Drouet B, Klein C, Koziel V, PinçonRaymond M, Olivier JL, Chambaz J, Pillot T (2003) Apoptotic neuronal cell death induced by the non-fibrillar amyloid-beta peptide proceeds through an early reactive oxygen species-dependent cytoskeleton perturbation. J Biol Chem 278, 3437-3445.

[20] Chauhan A, Chauhan V (2012) Potential beneficial effects of a diet with walnuts in aging and Alzheimer's disease. In Brain Aging and Therapeutic Interventions, Thakur MK, Rattan SIS, eds. Springer Science+Business Media, Dordrecht, pp. 239-252.

[21] Petersson SD, Philippou E (2016) Mediterranean diet, cognitive function, and dementia: A systematic review of the evidence. Adv Nutr 7, 889-904.

[22] Poulose SM, Miller MG, Shukitt-Hale B (2014) Role of walnuts in maintaining brain health with age. $J$ Nutr 144, 561S-566S.

[23] Muthaiyah B, Essa MM, Lee M, Chauhan V, Kaur K, Chauhan A (2014) Dietary supplementation of walnuts improves memory deficits and learning skills in transgenic mouse model of Alzheimer's disease. J Alzheimers Dis 42, 1397-1405.

[24] Chauhan N, Wang KC, Wegiel J, Malik MN (2004) Walnut extract inhibits the fibrillization of amyloid beta-protein, and also defibrillizes its preformed fibrils. Curr Alzheimer Res 1, 183-188.

[25] Martinez-Lapiscina EH, Clavero P, Toledo E, Estruch R, Salas-Salvadó J, San Julian B, Sanchez-Tainta A, Ros E, Valls-Pedret C, Martinez-Gonzalez MÁ (2013) Mediterranean diet improves cognition: The PREDIMEDNAVARRA randomised trial. J Neurol Neurosurg Psychiatry 84, 1318-1325.

[26] Valls-Pedret C, Sala-Vila A, Serra-Mir M, Corella D, de la Torre R, Martínez-González MÁ, Martinez-Lapiscina EH, Fitó M, Pérez-Heras A, Salas-Salvadó J, Estruch R, Ros E (2015) Mediterranean diet and age-related cognitive 
decline: A randomized clinical trial. JAMA Intern Med 175, 1094-1103.

[27] O'Brien J, Okereke O, Devore E, Rosner B, Breteler M, Grodstein F (2014) Long-term intake of nuts in relation to cognitive function in older women. J Nutr Health Aging 18, 496-502.

[28] Arab L, Ang A (2015) A cross sectional study of the association between walnut consumption and cognitive function among adult US populations represented in NHANES. J Nutr Health Aging 19, 284-290.

[29] Anderson KJ, Teuber SS, Gobeille A, Cremin P, Waterhouse AL, Steinberg FM (2001) Walnut polyphenolics inhibit in vitro human plasma and LDL oxidation. J Nutr 131, 28372842.

[30] Fukuda T, Ito H, Yoshida T (2003) Antioxidative polyphenols from walnuts (Juglans regia L.). Phytochemistry 63, 795-801.

[31] Halvorsen BL, Carlsen MH, Phillips KM, Bøhn SK, Holte K, Jacobs DR Jr, Blomhoff R (2006) Content of redoxactive compounds (ie, antioxidants) in foods consumed in the United States. Am J Clin Nutr 84, 95-135.

[32] Jurd L (1956) Plant polyphenols. I. The polyphenolic constituents of the pellicle of the walnut (Juglans regia). J Am Chem Soc 78, 3445-3448.

[33] Lavedrine F, Ravel A, Poupard A, Alary J (1997) Effect of geographic origin, variety and storage on tocopherol concentrations in walnuts by HPLC. Food Chem 58, 135-140

[34] Reiter RJ, Manchester LC, Tan DX (2005) Melatonin in walnuts: Influence on levels of melatonin and total antioxidant capacity of blood. Nutrition 21, 920-924.

[35] Mishra N, Dubey A, Mishra R, Barik N (2010) Study on antioxidant activity of common dry fruits. Food Chem Toxicol 48, 3316-3320.

[36] Muthaiyah B, Essa MM, Chauhan V, Chauhan A (2011) Protective effects of walnut extract against amyloid beta peptide-induced cell death and oxidative stress in PC12 cells. Neurochem Res 36, 2096-2103.

[37] Bu XL, Xiang Y, Jin WS, Wang J, Shen LL, Huang ZL, Zhang K, Liu YH, Zeng F, Liu JH, Sun HL, Zhuang ZQ, Chen SH, Yao XQ, Giunta B, Shan YC, Tan J, Chen XW, Dong ZF, Zhou HD, Zhou XF, Song W, Wang YJ (2017) Blood-derived amyloid- $\beta$ protein induces Alzheimer's disease pathologies. Mol Psychiatry. doi: 10.1038/mp.2017.204

[38] Sutcliffe JG, Hedlund PB, Thomas EA, Bloom FE, Hilbush BS (2011) Peripheral reduction of $\beta$-amyloid is sufficient to reduce brain $\beta$-amyloid: Implications for Alzheimer's disease. J Neurosci Res 89, 808-814.

[39] Kim DG, Krenz A, Toussaint LE, Maurer KJ, Robinson SA, Yan A, Torres L, Bynoe MS (2016) Non-alcoholic fatty liver disease induces signs of Alzheimer's disease (AD) in wildtype mice and accelerates pathological signs of $\mathrm{AD}$ in an AD model. J Neuroinflammation $\mathbf{1 3}, 1$.

[40] Socci DJ, Bjugstad KB, Jones HC, Pattisapu JV, Arendash GW (1999) Evidence that oxidative stress is associated with the pathophysiology of inherited hydrocephalus in the H-Tx rat model. Exp Neurol 155, 109-117.

[41] Anand T, Phani Kumar G, Pandareesh MD, Swamy MS, Khanum F, Bawa AS (2012) Effect of bacoside extract from Bacopa monniera on physical fatigue induced by forced swimming. Phytother Res 26, 587-593.

[42] Bagnyukova TV, Storey KB, Lushchak VI (2003) Induction of oxidative stress in Rana ridibunda during recovery from winter hibernation. $J$ Therm Biol 28, 21-28.
[43] Aebi H (1984) Catalase in vitro. Methods Enzymol 105, 121-126.

[44] Flohé L, Günzler, WA (1984) [12] Assays of glutathione peroxidase. Methods Enzymol 105, 114-120.

[45] Bradford MM (1976) A rapid and sensitive method for the quantitation of microgram quantities of protein utilizing the principle of protein-dye binding. Anal Biochem 72, 248-254.

[46] Massaad CA (2011) Neuronal and vascular oxidative stress in Alzheimer's disease. Curr Neuropharmacol 9, 662-673.

[47] Zhao Y, Zhao B (2013) Oxidative stress and the pathogenesis of Alzheimer's disease. Oxid Med Cell Longev 2013, 316523.

[48] Kawarabayashi T, Younkin LH, Saido TC, Shoji M, Ashe KH, Younkin SG (2001) Age-dependent changes in brain, CSF, and plasma amyloid (beta) protein in the Tg2576 transgenic mouse model of Alzheimer's disease. J Neurosci 21, 372-381.

[49] Amaral JS, Seabra RM, Andrade PB, Valentão P, Pereira JA, Ferreres F (2004) Phenolic profile in the quality control of walnut (Juglans regia L.) leaves. Food Chem 88, 373-379.

[50] Pereira JA, Oliveira I, Sousa A, Valentão P, Andrade PB, Ferreira IC, Ferreres F, Bento A, Seabra R, Estevinho L (2007) Walnut (Juglans regia L.) leaves: Phenolic compounds, antibacterial activity and antioxidant potential of different cultivars. Food Chem Toxicol 45, 2287-2295.

[51] Stampar F, Solar A, Hudina M, Veberic R, Colaric M (2006) Traditional walnut liqueur-cocktail of phenolics. Food Chem 95, 627-631.

[52] Shi DD, Chen CY, Zhao SL, Ge F, Liu DQ, Song H (2014) Effects of walnut polyphenol on learning and memory functions in hypercholesterolemia mice. J Food Nutr Res 2, 450-456.

[53] Dalle-Donne I, Rossi R, Giustarini D, Milzani A, Colombo R (2003) Protein carbonyl groups as biomarkers of oxidative stress. Clin Chim Acta 329, 23-38.

[54] Safwat MH, El-Sawalhi MM, Mausouf MN, Shaheen AA (2014) Ozone ameliorates age-related oxidative stress changes in rat liver and kidney: Effects of pre- and postageing administration. Biochemistry (Mosc) 79, 450-458.

[55] Aksenov MY, Aksenova MV, Butterfield DA, Geddes JW, Markesbery WR (2001) Protein oxidation in the brain in Alzheimer's disease. Neuroscience 103, 373-383.

[56] Smith CD, Carney JM, Starke-Reed PE, Oliver CN, Stadtman ER, Floyd RA, Markesbery WR (1991) Excess brain protein oxidation and enzyme dysfunction in normal aging and in Alzheimer disease. Proc Natl Acad Sci U S A 88, 10540-10543.

[57] Castegna A, Aksenov M, Aksenova M, Thongboonkerd V, Klein JB, Pierce WM, Booze R, Markesbery WR, Butterfield DA (2002) Proteomic identification of oxidatively modified proteins in Alzheimer's disease brain. Part I: Creatine kinase BB, glutamine synthase, and ubiquitin carboxy-terminal hydrolase L-1. Free Radic Biol Med 33, $562-571$.

[58] Haider S, Batool Z, Ahmad S, Siddiqui RA, Haleem DJ (2018) Walnut supplementation reverses the scopolamineinduced memory impairment by restoration of cholinergic function via mitigating oxidative stress in rats: A potential therapeutic intervention for age related neurodegenerative disorders. Metab Brain Dis 33, 39-51.

[59] Choi JG, Park G, Kim HG, Oh DS, Kim H, Oh MS (2016) In vitro and in vivo neuroprotective effects of walnut (Juglandis semen) in models of Parkinson's disease. Int J Mol Sci 17, E108. 
[60] Sánchez-Villegas A, Martinez-González MA, Estruch R, Salas-Salvadó J, Corella D, Covas MI, Arós F, Romaguera D, Gómez-Gracia E, Lapetra J, Pintó X, Martinez JA, Lamuela-Raventós RM, Ros E, Gea A, Warnberg J, Serra-Majem L (2013) Mediterranean dietary pattern and depression: The PREDIMED randomized trial. BMC Med 11, 208.

[61] Ros E (2015) Nuts and CVD. Br J Nutr 113(Suppl 2), S111S120.

[62] Asadi-Shekaari M, Kalantaripour TP, Nejad FA, Namazian E, Eslami A (2012) The anticonvulsant and neuroprotective effects of walnuts on the neurons of rat brain cortex. Avicenna J Med Biotechnol 4, 155-158.

[63] Banel DK, Hu FB (2009) Effects of walnut consumption on blood lipids and other cardiovascular risk factors: A metaanalysis and systematic review. Am J Clin Nutr 90, 56-63.

[64] Kris-Etherton PM (2014) Walnuts decrease risk of cardiovascular disease: A summary of efficacy and biologic mechanisms. J Nutr 144, 547S-554S.

[65] Sabaté J, Fraser GE, Burke K, Knutsen SF, Bennett H, Lindsted KD (1993) Effects of walnuts on serum lipid levels and blood pressure in normal men. $N$ Engl J Med 328, 603-607.

[66] Djoussé L, Lu B, Gaziano JM (2016) Effects of walnut consumption on endothelial function in people with type 2 diabetes: A randomized pilot trial. Curr Nutr Rep 5, 1-8.

[67] Pan A, Sun Q, Manson JE, Willett WC, Hu FB (2013) Walnut consumption is associated with lower risk of type 2 diabetes in women. $J$ Nutr 143, 512-518.

[68] Hardman WE (2014) Walnuts have potential for cancer prevention and treatment in mice. J Nutr 144, 555S-560S.
[69] Hardman WE, Ion G (2008) Suppression of implanted MDA-MB 231 human breast cancer growth in nude mice by dietary walnut. Nutr Cancer 60, 666-674.

[70] Hardman WE, Ion G, Akinsete JA, Witte TR (2011) Dietary walnut suppressed mammary gland tumorigenesis in the C(3)1 TAg mouse. Nutr Cancer 63, 960-970.

[71] Davis PA, Vasu VT, Gohil K, Kim H, Khan IH, Cross CE, Yokoyama W (2012) A high-fat diet containing whole walnuts (Juglans regia) reduces tumour size and growth along with plasma insulin-like growth factor 1 in the transgenic adenocarcinoma of the mouse prostate model. Br J Nutr 108, 1764-1772.

[72] Reiter RJ, Tan DX, Manchester LC, Korkmaz A, FuentesBroto L, Hardman WE, Rosales-Corral SA, Qi W (2013) A walnut-enriched diet reduces the growth of $\mathrm{LNCaP}$ human prostate cancer xenografts in nude mice. Cancer Invest 31, 365-373.

[73] Chung J, Kim YS, Lee J, Lee JH, Choi SW, Kim Y (2016) Compositional analysis of walnut lipid extracts and properties as an anti-cancer stem cell regulator via suppression of the self-renewal capacity. Food Sci Biotechnol 25, 623-629.

[74] Lee J, Kim YS, Lee J, Heo SC, Lee KL, Choi SW, Kim Y (2016) Walnut phenolic extract and its bioactive compounds suppress colon cancer cell growth by regulating colon cancer stemness. Nutrients $\mathbf{8}$, E439.

[75] Nakanishi M, Chen Y, Qendro V, Miyamoto S, Weinstock E, Weinstock GM, Rosenberg DW (2016) Effects of walnut consumption on colon carcinogenesis and microbial community structure. Cancer Prev Res (Phila) 9, 692-703. 